Life Sciences Contributions Royal Ontario Museum

Redescription of Type Specimens of Species of the Bryozoan Genera Monticulipora, Mesotrypa, Peronopora, and Prasopora, from the Upper Ordovician Rocks of Toronto and Vicinity, Ontario, Canada

Madeleine A. Fritz

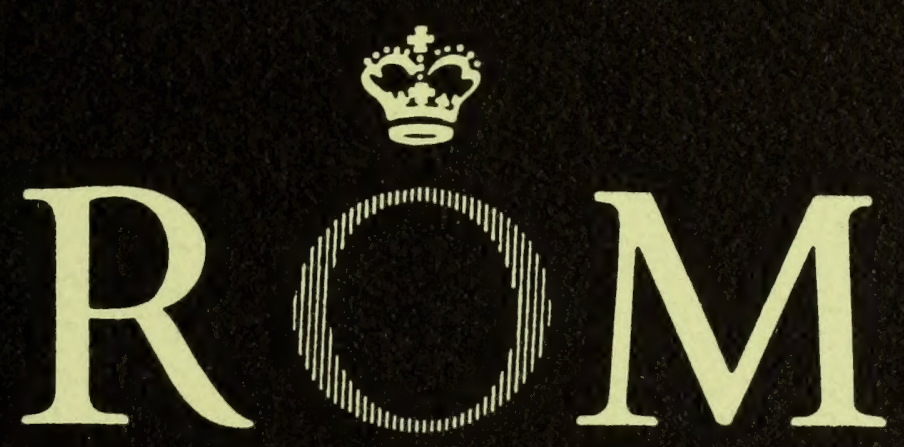


Digitized by the Internet Archive in 2011 with funding from University of Toronto 
LIFE SCIENCES CONTRIBUTIONS

ROYAL ONTARIO MUSEUM

NUMBER 107

Madeleine A. FRITz Redescription of Type Specimens of Species of the Bryozoan Genera Monticulipora, Mesotrypa, Peronopora, and Prasopora, from the Upper Ordovician Rocks of Toronto and Vicinity, Ontario, Canada 


\section{ROYAL ONTARIO MUSEUM \\ PUBLICATIONS IN LIFE SCIENCES}

The Royal Ontario Museum publishes three series in the Life Sciences:

LIFE SCIENCES CONTRIBUTIONS, a numbered series of original scientific publications, including monographic works.

LIFE SCIENCES OCCASIONAL PAPERS, a numbered series of original scientific publications, primarily short and usually of taxonomic significance.

LIFE SCIENCES MISCELLANEOUS PUBLICATIONS, an unnumbered series of publications of varied subject matter and format.

All manuscripts considered for publication are subject to the scrutiny and editorial policies of the Life Sciences Editorial Board, and to review by persons outside the Museum staff who are authorities in the particular field involved.

\section{LIFE SCIENCES EDITORIAL BOARD}

Chairman: WALTER M. TOVELL

Editor: A. R. EMERY

Associate Editor: I. R. BALL

Associate Editor: J. C. BARLOW

MADeleine A. FRITZ is a Research Associate in the Department of Invertebrate Palaeontology, Royal Ontario Museum, Toronto, Ontario.

PRICE: $\$ 1.50$

(C) The Royal Ontario Museum, 1976

100 Queen's Park, Toronto, Canada

PRINTED AND BOUND IN CANADA AT THE BRYANT PRESS LIMITED 


\title{
Redescription of Type Specimens of Species of the Bryozoan Genera Monticulipora, Mesotrypa, Peronopora, and Prasopora, from the Upper Ordovician Rocks of Toronto and Vicinity, Ontario, Canada
}

\begin{abstract}
The species Prasopora donensis Parks and Dyer, Peronopora vera Nickles and Mesotrypa distincta Parks have been previously identified and described from the Upper Ordovician rocks of Toronto and vicinity. The sub-species Monticulipora parasitica multipora Dyer is herein accorded specific rank. The type specimens of these species are redescribed using qualitative and quantitative methods together with improved illustrations. A new species, Prasopora richmondensis sp.nov., is described from the same stratigraphic horizon.
\end{abstract}

\section{Introduction}

The Upper Ordovician rocks that underlie Toronto and vicinity are included in the Georgian Bay Formation (Liberty, 1969). Prior to 1969 two formations were recognized, namely, Dundas (Parks, 1924) and Meaford (Foerste, 1924). These two formations were correlated respectively with the Maysville and Richmond of Ohio. The Dundas Formation was divided by Parks (1924) and Dyer (1925) in ascending order into the Rosedale, Danforth, Humber and Credit Members; the Meaford into Erindale, Streetsville and Meadowvale Members. Parks and Dyer (1922) described the Bryozoa of the Dundas Formation; Dyer (1925) described the Bryozoa of the Meaford Formation. Armstrong (1945) studied in greater detail the genus Stigmatella. Since the descriptions of the above workers do not meet present standards, I began a study of the specimens which the authors designated as types and which at present are located in the Department of Invertebrate Palaeontology in the ROM (Fritz, 1970, 1971, 1973, 1975). This study has resulted in more detailed qualitative descriptions, in quantitative analyses, and in improved illustrations. The present paper deals similarly with the type specimens of species of the genera Mesotrypa, Monticulipora, Peronopora, and Prasopora. 


\section{Materials and Methods}

The specimens studied in this paper include:

Mesotrypa distincta Parks, 1925

Monticulipora parasitica multipora Dyer, 1925 (herein designated M. multipora)

Peronopora vera Nickles, 1905

Prasopora donensis Parks and Dyer, 1922

Prasopora richmondensis sp.nov.

In addition, the following type specimens have been kindly loaned to me for comparison with the ROM types:

Monticulipora multipora Utgaard and Perry, Indiana University, Hypotype No.

8252 (plus 8 micro sections of this Hypotype, Nos. 1051, 1284, 1388, 1599, $1645,1646,1647,1648)$.

Peronopora vera Ulrich, United States National Museum, Holotype No. 43943.

Prasopora nodosa Ulrich, United States National Museum, Holotype No. 43691.

The external features of the zoaria (i.e., shape of the colony, character of the surface) were observed with the aid of a hand lens, but the internal structures of each species were determined by means of thin sections. While the descriptions are two-dimensional, that is, as to what is seen in each of the standard views, nevertheless, three-dimensional relationships of the interior of the colonies are, to a certain extent, inferred. A study based on three-dimensional relationships is outside the purpose of the present research. The mensuration of the number of zooecia in $2 \mathrm{~mm}$ in the intermonticular areas and measurements in millimetres of the maximum dimension of zooecial apertures in the monticular and intermonticular areas were made with the aid of a binocular microscope and a micrometer scale calibrated to $0.01 \mathrm{~mm}$. The number of entire mesopores and the number of entire acanthopores in $1 \mathrm{~mm}^{2}$ were obtained by using a compound microscope and a reticle calibrated to $1 \mathrm{~mm}^{2}$. Statistical computations were made on the IBM $370 / 165$ computer at the University of Toronto Computer Centre. As most of the samples had heterogeneous variances it was not possible to test differences among means using parametric statistical methods. Instead, the samples were tested for differences in dispersion using the non-parametric MannWhitney U-test (Siegel, 1956). In the tables probability ranges associated with significance tests are designated with asterisks as follows: $* * *=P \leq 0.001$; ${ }^{*}=P \leq 0.01 ; *=P \leq 0.1$; not significant $=\mathrm{ns}=P>0.05$. 


\section{Systematic Palaeontology}

Order Trepostomata Ulrich, 1882a

Family Monticuliporidae Nicholson, 1879

Genus Monticulipora D’Orbigny, 1849

\section{Description}

Emended description of Monticulipora in Boardman and Utgaard, 1966.

\section{Type Species}

Monticulipora mammulata D’Orbigny, 1849: 25.

\section{Monticulipora multipora Dyer, 1925 \\ Fig. 1A, B}

Monticulipora parasitica multipora Dyer, 1925: 71.

Monticulipora multipora-Utgaard and Perry, 1964: 43.

\section{Original Description (Dyer, 1925)}

Two specimens were obtained from the Streetsville member which appear to belong to Monticulipora parasitica except for the fact that they possess numerous mesopores. In this respect they agree with the form described and figured by Cumings from the Liberty of Indiana, as belonging to this species. The apparent identity of our specimens with those of Cumings and the constant departure from the type of the species, as indicated by the presence of mesopores, seems to justify the creation of a new variety. The new variety resembles $M$. cincinnatiensis, as stated by Cumings, but it differs in having acanthopores and in the lower type of monticule.

\section{Emended Description}

Dyer designated two syntypes, ROM 12168 and ROM 12169. The following description of syntype 12168 , now the lectotype of $M$. multipora, adds significantly to that of Dyer (1925). Syntype 12169 is another species (to be considered later).

\section{EXTERNAL FEATURES}

Zoarium an overgrowth on a small dome-shaped mound of sediment and fossil debris, $15 \mathrm{~mm}$ wide $\times 10 \mathrm{~mm}$ high, at the base of which a fragment of Isotelus occurs. Thickness of zoarium $2 \mathrm{~mm}$, surface of zoarium with prominent, conical monticules, spaced 2 to $2.5 \mathrm{~mm}$ apart measuring from centre to centre.

\section{TANGENTJAL SECTION}

Zooecia subcircular to circular, 9 to 11 in $2 \mathrm{~mm}$ (Table 1). Zooecial wall granular, knotty in appearance owing to irregular size of granules, $0.01 \mathrm{~mm}$ (or less) thick below surface; $0.02 \mathrm{~mm}$ near surface and up to $0.03 \mathrm{~mm}$ in monticules, thin zooecial lining, concentrically laminated, best observed near surface. Angular mesopores varying in shape and size, from small to one-third size of zooecia, surround most zooecia (Table 1). Acanthopores absent. In the wall, minute round dots, with lucid centres, represent granules with clear interiors (Ulrich regarded these lucid spots as acanthopores). Monticules with small mesopores interspersed among zooecia which are larger than the zooecia in intermonticular areas, maxi- 


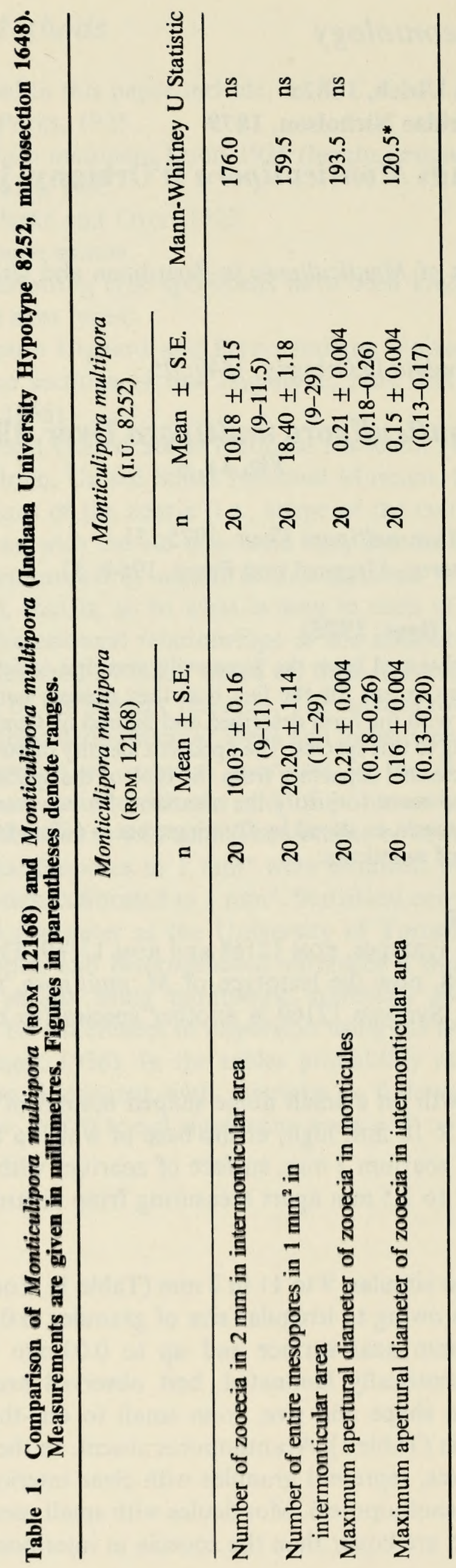




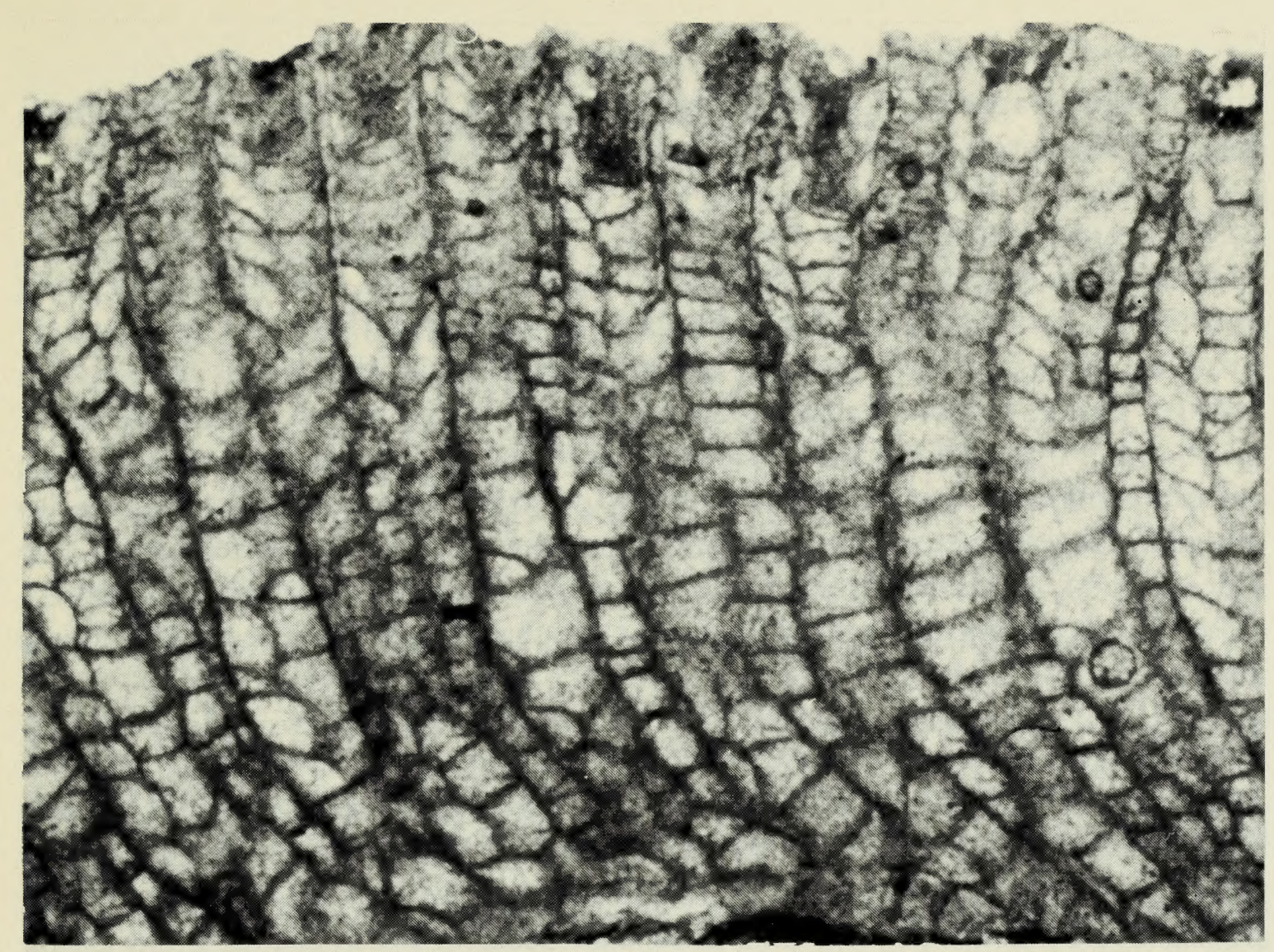

A

B

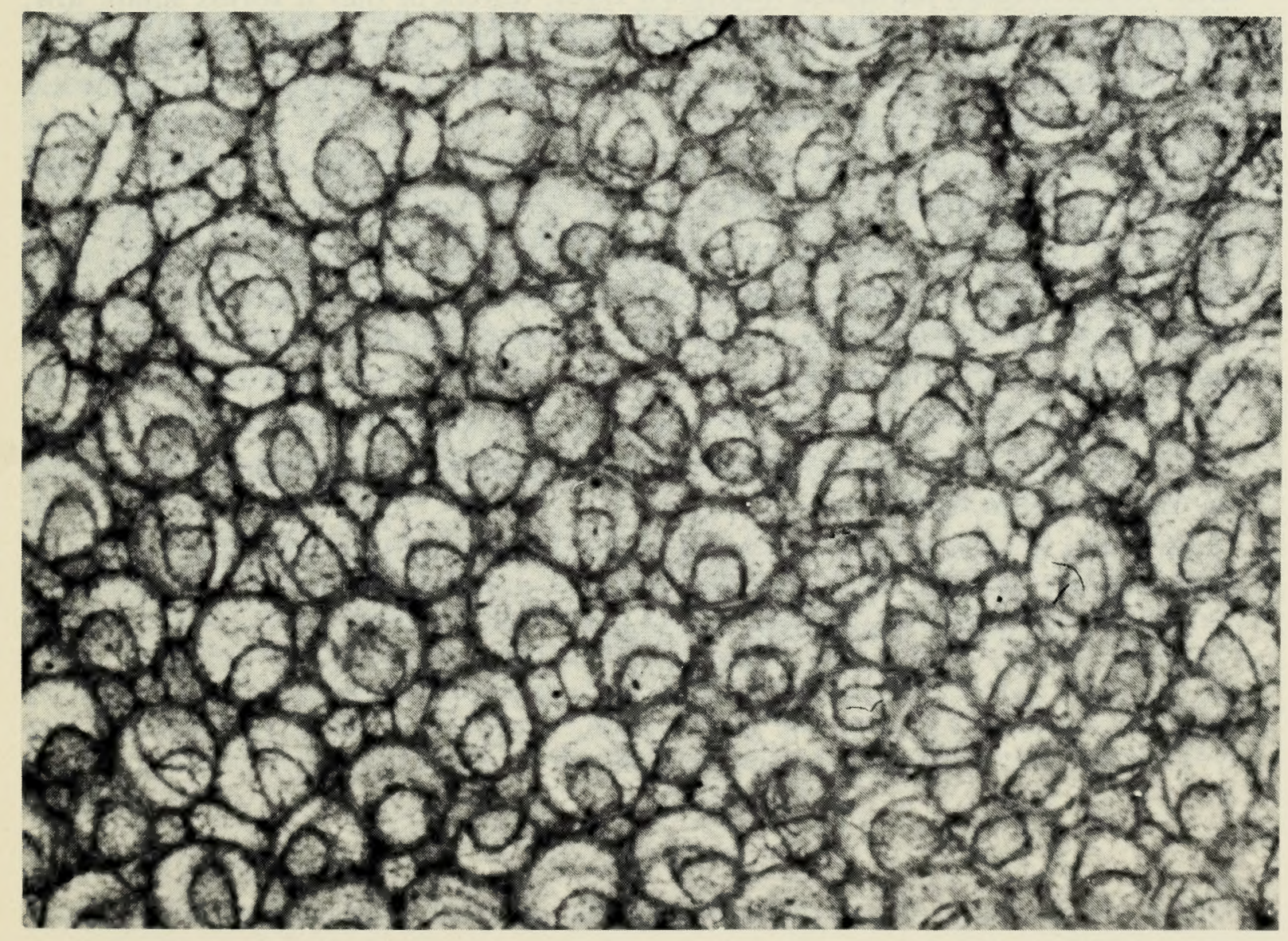

Fig. 1 A-B. Monticulipora multipora Dyer, lectotype Rом 12168.

A. Longitudinal section, $\times 48.6$

B. Tangential section, $\times 48.6$ 
mum zooecial aperture in $\mathrm{mm}$ in monticules $0.18-0.26$ (Table 1 ); maximum diameter of zooecia in $\mathrm{mm}$ in intermonticular areas $0.13-0.20$ (Table 1).

\section{LONGITUDINAL SECTION}

Zooecia either subprostrate or erect above base of zoarium, thereafter proceeding directly to surface of zoarium. Walls thin throughout, knotty or minutely wrinkled, owing to their granular nature, thin zooecial lining best observed in younger part of section. Straight diaphragms and overlapping cystiphragms occur in zooecia, their arrangement varies from half diaphragms and overlapping cystiphragms near the surface to diaphragms only near surface, spaced one to one-half tube diameter apart; cystiphragms usually in single series and in the older part of zooecium, rarely in double series. Mesopores numerous and with close-set diaphragms, commonly spaced one tube diameter apart. Acanthopores absent.

\section{Remarks}

Monticulipora parasitica Ulrich, $1882 \mathrm{~b}$ and Monticulipora parasitica multipora Dyer, 1925 are similar in habit of growth, but in $M$. parasitica the zooecia are angular and the monticules are composed of aggregations of small mesopores surrounded by larger zooecia than those that occur in the intermonticular areas; furthermore, few mesopores occur in the intermonticular area.

Monticulipora epidermata Ulrich and Bassler, 1904 which shows affinities with Monticulipora parasitica multipora Dyer, differs in that it forms small, low, hemispherical masses to thin plate-like zoaria, which give off branches or knoblike protusions; mesopores in intermonticular areas are few and small, and mostly confined to the centres of monticules.

Utgaard and Perry (1964: 43), although they did not examine Dyer's type, identified and described his taxon from specimens collected from the Whitewater Formation of eastern Indiana and western Ohio; they referred to their specimens as Monticulipora multipora. I have examined hypotype No. 8252 from Indiana University and find that it is very similar to Dyer's type qualitatively. Quantitatively only a slight difference is noted in the maximum aperture diameter of the zooecia in the intermonticular areas (Table 1). I therefore agree with Utgaard and Perry that Dyer's variety should be given specific rank and known henceforth as Monticulipora multipora.

\section{Locality}

Meaford Formation, Streetsville, Ontario.

\section{Type}

Lectotype ROM 12168. 


\section{Mesotrypa Ulrich, 1893}

Type Species

Diplotrypa infida Ulrich, 1886.

\section{Mesotrypa distincta Parks, 1925}

Fig. 2A, B

Mesotrypa (?) sp.nov., Parks and Dyer, 1922: 5.

Mesotrypa distincta Parks, 1925: 36.

\section{Original Descriptions}

Parks and Dyer's 1922 description of Mesotrypa (?) sp.nov. follows:

Of frequent occurrence on the Humber river is a discoidal bryozoan with a concentrically wrinkled epitheca which may attain a diameter of $25 \mathrm{~mm}$. The surface is gently convex and practically smooth; the under side is correspondingly concave. The thickness varies, and superposition of layers is not uncommon; a single layer is generally about one millimetre thick.

The surface shows, in places, sub-quadrate zooecial openings more or less regularly arranged and occurring to the number of nine in the space of two millimetres: in these areas the walls seem to be in contact. In other parts of the surface the openings are larger, more rounded, and separated by distinct interspaces although the zooecia are never completely out of touch with each other.

Tangential sections show that the walls are moderately thick and independent even where the mesopores are absent and the zooecial walls in close contact. Very small acanthopores are sparingly developed. Vertical sections show the zooecial tubes to arise with a slight slant from the basal plate and to proceed almost directly to the surface with walls of practically the same thickness throughout. The zooecial tubes are crossed by numerous irregular diaphragms for about two-thirds of their length; the peripheral third seems to be devoid of internal structures. The diaphragms are slanting and irregular and occasionally simulate cystiphragms. Between the zooecial tubes are numerous mesopores, crossed by close-set, horizontal diaphragms, which continue to the surface. These mesopores show distinct evidence, in places, of narrowing towards the surface of the polyzoarium.

\section{Parks' description in 1925 of Mesotrypa distincta follows:}

Numerous and better species of this discoidal bryozoan have been found since Part II appeared. The description therein is accurate and needs little addition. Good vertical sections show a most distinct pinching-out of the mesopores towards the surface. In some cases, however, the mesopores continue to the surface with no diminution in diameter. Shallow tangential sections show only occasional mesopores, the point at which a mesopore might be expected to appear being occupied by an acanthopore. The species is found at various levels on the Humber and abundantly at the Prison Farm quarry.

\section{Emended Description}

Among the type material labelled Mesotrypa distincta, six syntypes are represented. The original description was based on only one of the syntypes, now designated lectotype ROM $1200 \mathrm{HR}$. The remaining specimens were not sectioned by Parks and Dyer but sections prepared for the present study verify the accuracy of their identification. They become paralectotypes. 


\section{EXTERNAL FEATURES}

Zoarium free, hemispherical, diameter 15 to $17 \mathrm{~mm}, 1.5 \mathrm{~mm}$ thick, slightly convex above, base correspondingly concave with concentrically wrinkled epitheca; surface with maculae flush with surface, normally $2.5 \mathrm{~mm}$ apart measuring from centre to centre and consisting of zooecia larger than those in the intermacular areas.

\section{TANGENTIAL SECTION}

Zooecia angular to subangular near surface, subcircular to circular below surface, shape depending on number of mesopores present at a given depth, eight to nine zooecia in intermacular areas (Table 2). Zooecial walls uniformly thin $0.01 \mathrm{~mm}$ in genera!, $0.02 \mathrm{~mm}$ in maculae, concentrically laminated, laminae very fine, distinguishable best under magnification of $\times 250$; where two zooecia in contact a dark area present formed from the combined laminae of the adjacent pair. Mesopores numerous in $1 \mathrm{~mm}^{2}$ (Table 2) mostly rectangular, or triangular, more numerous and larger at depth where they may surround zooecia in one or two rows thus rendering zooecia circular to subcircular; mesopores become smaller towards surface and at times peter out, leaving dense tips which might suggest acanthopores, here zooecia become subangular to angular. Acanthopores absent. Maculae composed of larger zooecia than those in intermacular areas, some with large mesopores. Maximum apertural diameter of zooecia in $\mathrm{mm}$ in macular areas 0.19-0.26 (Table 1); maximum apertural diameter in $\mathrm{mm}$ in intermacular areas 0.14-0.16 (Table 2).

\section{LONGITUDINAL SECTION}

Zooecia and mesopores subprostrate for short distance, erect centrally, all proceed directly to surface. Zooecial walls thin; diaphragms straight, curved, oblique, infundibular, rarely cystoid, occur throughout zooecia, spaced one to one and a half tube diameters apart. Mesopores singly or in groups of two or three, many terminate before reaching zooecial surface; diaphragms uniformly spaced, commonly 19 to 30 in $1 \mathrm{~mm}$.

\section{Remarks}

The presence or absence of acanthopores is a distinguishing feature of Mesotrypa species. M. discoidea Ulrich (1893: 260), M. quebecensis (Ami, 1892: 101),

Table 2. Measurements of the taxonomic characters of Mesotrypa distincta. Measurements are given in millimetres. Figures in parentheses denote ranges.

\begin{tabular}{lcc}
\hline & $\mathrm{n}$ & Mean \pm S.E. \\
\hline Number of zooecia in $2 \mathrm{~mm}$ in intermonticular area & 20 & $\begin{array}{c}8.5 \pm 0.10 \\
(8-9)\end{array}$ \\
Number of entire mesopores in $1 \mathrm{~mm}^{2}$ in intermonticular area & 20 & $\begin{array}{c}22.5 \pm 0.98 \\
(16-31)\end{array}$ \\
Maximum apertural diameter of zooecia in monticules & & $0.2 \pm 0.006$ \\
Maximum apertural diameter of zooecia in intermonticular area & 20 & $(0.19-0.26)$ \\
& & $0.2 \pm 0.003$ \\
& & $(0.14-0.18)$ \\
\hline
\end{tabular}




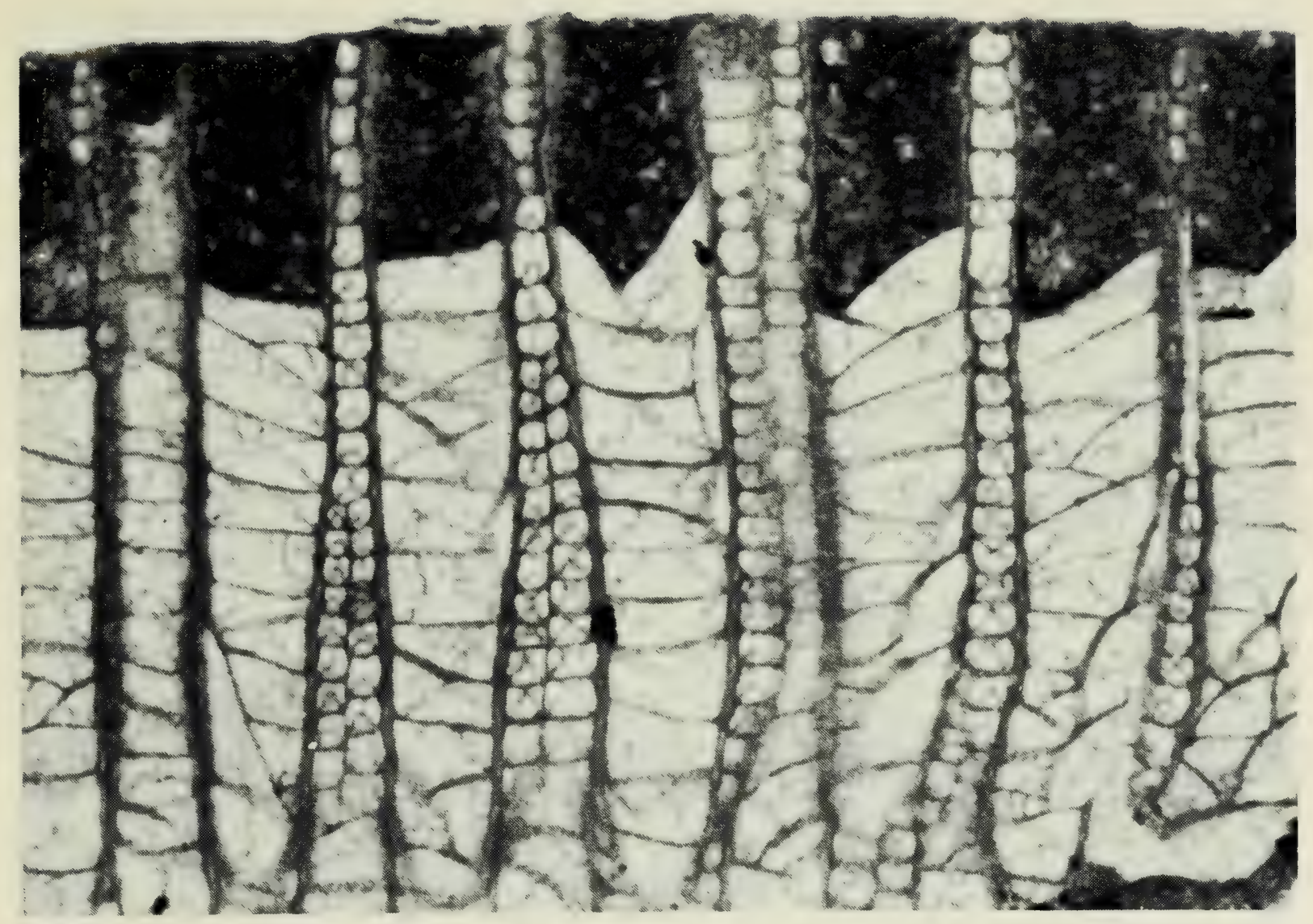

A

B

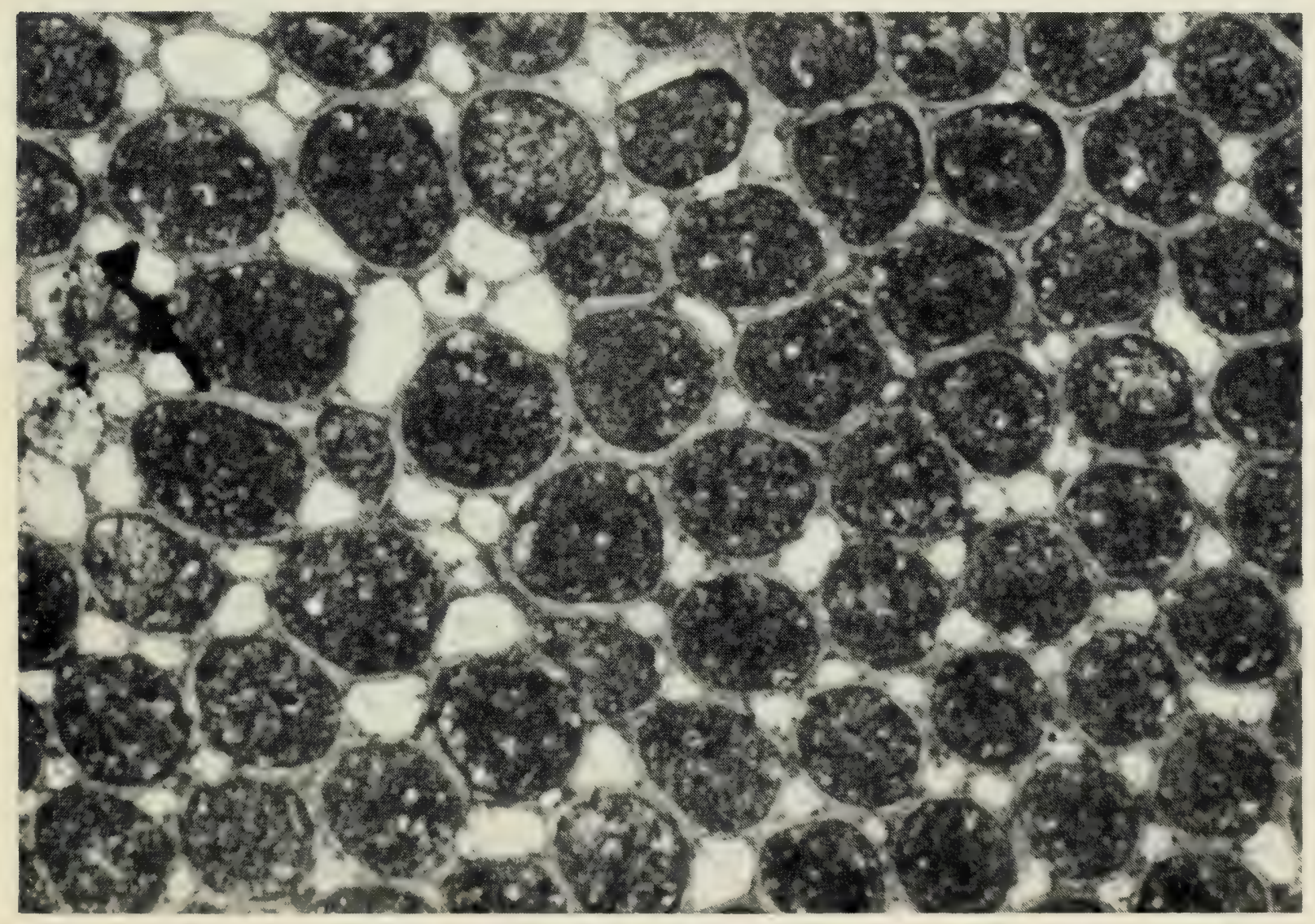

Fig. 2 А-в. Mesotrypa distincta Parks, lectotype, ROM 1200HR.

A. Longitudinal section, $\times 48.6$

B. Tangential section, $\times 48.6$ 
and $M$. rotunda Ulrich $(1893: 262)$ from the Trenton all lack acanthopores, as does $M$. distincta from the Humber Member, Dundas Formation; these four species are similar when considered qualitatively, but no quantitative analysis is available for the Trenton taxa. Mesotrypa diversa (Fritz, 1971) from the Humber Member has acanthopores; however the zoarial shape and surface configuration of that species are unique among species known to the writer. $M$. patella (Ulrich, 1890: 458), $M$. orbiculoidea Cumings and Galloway (1913: 432), and $\boldsymbol{M}$. pauca Utgaard and Perry (1964: 69), all of Richmond age, have acanthopores. Of these species, $M$. distincta resembles most closely $M$. patella except for the absence of acanthopores in the former. Measurements of the taxonomic characters of $M$. distincta are recorded in Table 2; they may serve later in comparing similar taxa unknown at present to me. In view of the combination of features recognized in this taxon, I consider it to be a distinct species appropriately named Mesotrypa distincta.

\section{Locality}

Dundas Formation (Humber Member), Humber River, Toronto, Ontario.

Types

Lectotype ROM 1200HR; paralectotypes ROM 30726.

\section{Genus Peronopora Nicholson, 1881}

\section{Description}

Description of Peronopora revised by Boardman and Utgaard (1966).

\section{Type Species}

Chaetetes decipiens Rominger, 1886.

\section{Peronopora vera Nickles, 1905}

\section{Fig. 3A-D}

Peronopora vera Ulrich, 1888, nomen nudum

Peronopora vera Nickles, 1905: 46

Peronopora vera Ulrich - Parks and Dyer, 1922: 7.

\section{Description}

Parks and Dyer (1922) described this material as follows:

This species is not uncommon in the quarry on the Don River and has often been mistaken for Heterotrypa frondosa. The figures of tangential sections show the characteristic appearance of true tangential section on the left-hand side; on the right-hand side the section is deeper and slightly inclined showing both zooecial tubes and mesopores in inclined or longitudinal section. The vertical section, from a photomicrograph, is shown without retouching in Plate II, Figure 5; it is rather confused owing to the impossibility of cutting a section exactly parallel to the various elements. The drawing was made by combining the most typical parts shown by the same thin section. The median plane is marked by a very thin line on both sides of which appear the bases of the zooecial tubes and of the mesopores which seem to alternate with a considerable degree of regularity. The base of the zooecial tube is trapezoidal and small, that of the mesopore is hexagonal and larger. The mesopores are crossed by crowded diaphragms throughout: the zooecial tubes have diaphragms in the lower half and cystiphragms in the upper. 

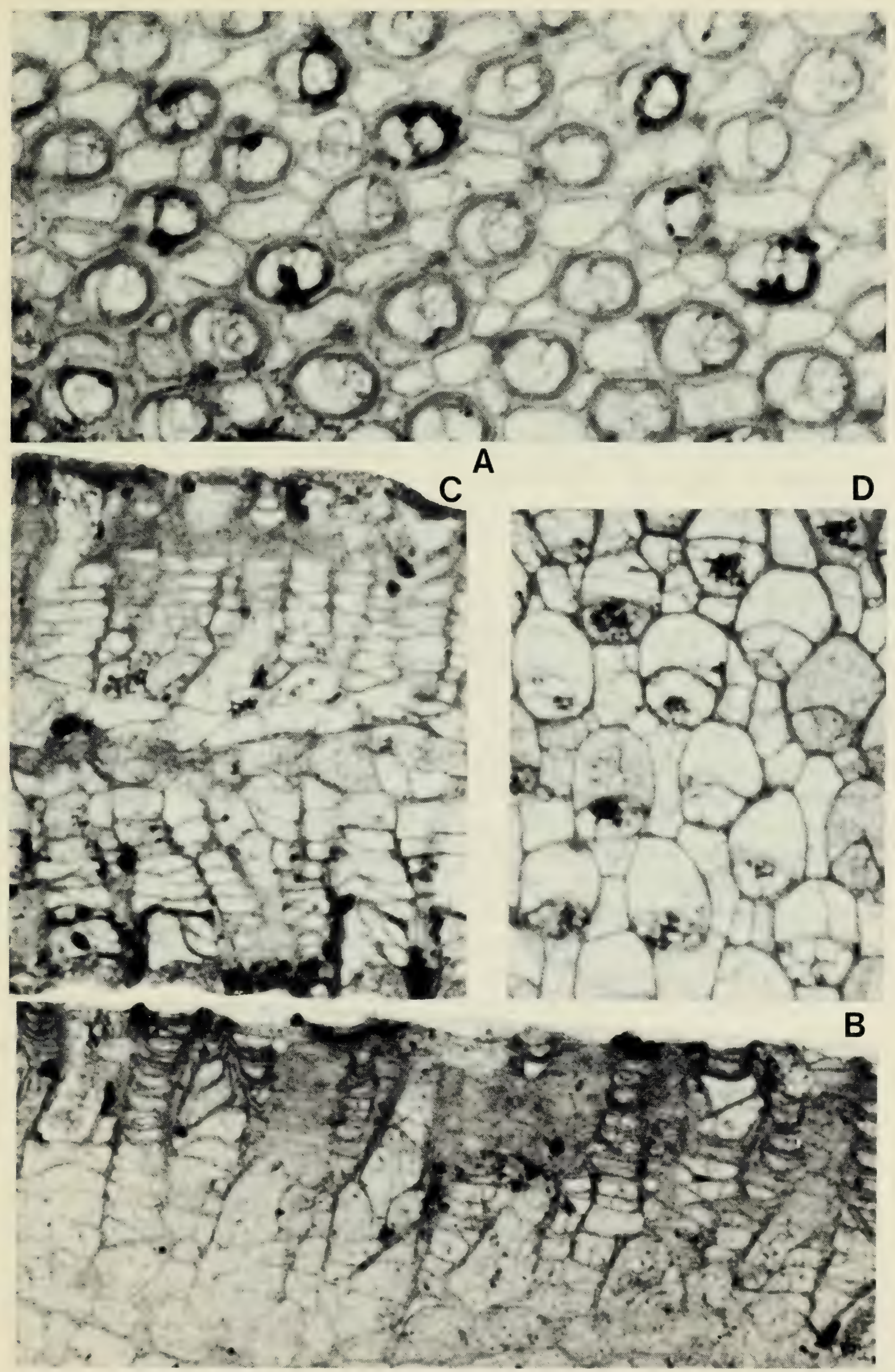

Fig. 3 A-D. Peronopora vera Nickles, plesiotype, ROM 1083HR.

A. Tangential section, $\times 48.6$

B. Longitudinal section, $\times 48.6$

C. Longitudinal section, $\times 48.6$

D. Tangential section, $\times 48.6$ 


\section{Emended Description}

Specimen, fragment of a subfrondescent, bifoliate zoarium, covers an area of 45 by $25 \mathrm{~mm}$ with maximum thickness of $2 \mathrm{~mm}$; a few small, rounded, irregularly spaced protuberances that rise above the surface, varying in size, may represent aborted branches. Surface with low monticules composed of zooecia larger than those in intermonticular areas. Acanthopores, blunt to somewhat pointed, protrude beyond the surface.

\section{TANGENTIAL SECTION}

Zooecial apertures near surface round to subangular, seven to eight in $2 \mathrm{~mm}$ (Table 3). Zooecial walls thin, $0.01 \mathrm{~mm}$ (or less) in deep sections, 0.02 to $0.03 \mathrm{~mm}$ at surface, and up to $0.04 \mathrm{~mm}$ in monticules, concentrically laminated. Mesopores numerous, surround zooecia (Table 3), angular to subangular, vary ng in size and shape, some with an areal extent close to that of certain zooecia, occasionally a cluster of mesopores in monticules. Acanthopores numerous, locally inflecting (Table 3), varying in diameter from 0.02 to $0.05 \mathrm{~mm}$ depending on where section cuts the structure, central lumen, surrounded by concentric laminae, lumen at times obscured by pyrite deposit. Monticules with larger zooecia than in intermonticular areas. Maximum apertural diameter of zooecia in monticular areas in mm 0.19-0.27 (Table 3); maximum apertural diameter of zooecia in intermonticular areas in mm $0.14-0.19$ (Table 3).

\section{LONGITUDINAL SECTION}

Zooecia prostrate for short distance on either side of mesotheca, then becoming erect to zoarial surface, or they may be erect to the surface from the outset; mesotheca with median lamella. Zooecial walls thin, laminae thickening slightly towards surface, lam nae convex outward, steeply inclined and merging with diaphragms and cystiphragms, and with diaphragms in mesopores. Diaphragms in zooecia straight, curved, or sigmoidal, commonly in immature zone, spaced one-quarter to one-half tube diameters apart and followed on distal wall by overlapping cystiphragms, in longer zooecia from six to nine diaphragms and cystiphragms occur. Above the immature zone, mesopores, mostly erect to surface, contain closely and regularly arranged, usually straight diaphragms. Acanthopores numerous, usually observed in wall, but at times seen to cross a zooecium obliquely, wall relatively coarsely laminate, laminae convex outward and diverging at a low angle from central lumen, then passing into diaphragms and cystiphragms.

\section{Remarks}

In 1888, Ulrich named Peronopora vera but he did not describe or figure it. His type No. 43943, with accompanying thin sections, is in the United States National Museum. Donald Dean has kindly loaned this material to me for comparison with Parks and Dyer's plesiotype. I find that the two are similar qualitatively and that no significant difference occurs quantitatively (Table 3 ).

\section{Locality}

Dundas Formation, Upper Ordovician, Don Valley Quarry, Toronto, Ontario.

\section{Type}

Plesiotype ROM 1083HR. 


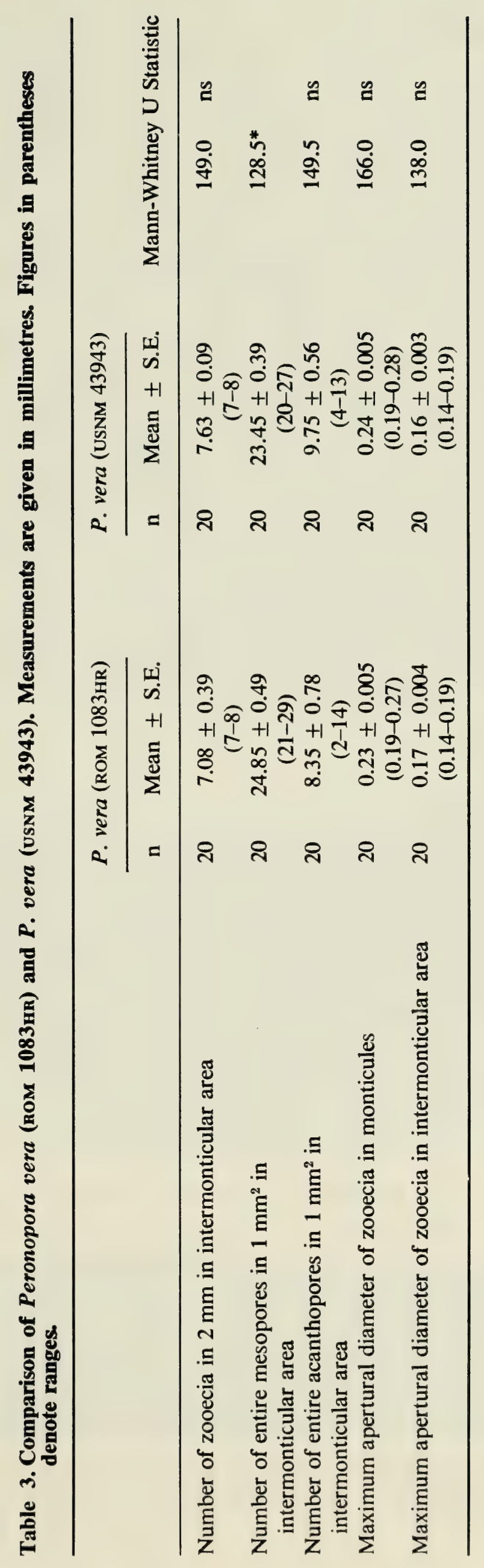




\section{Prasopora Nicholson and Etheridge, 1877}

\section{Description}

The description of Prasopora may be found in Ross (1970).

\section{Type Species}

Prasopora grayae Nicholson and Etheridge, 1877

\section{Prasopora donensis Parks and Dyer, 1922 Fig. 4A-C}

\section{Original Description (Parks and Dyer, 1922)}

The zoarium of this species is circular and free, probably with a concentrically wrinkled epitheca. The diameter ranges from 17 to $20 \mathrm{~mm}$ and the thickness is approximately one millimetre. The upper surface is gently convex and the under surface correspondingly concave. The celluliferous surface shows that the ordinary apertures are arranged in quincuncial rows springing from a number of very ill-defined centres. They are usually hexagonal in outline and occur to the number of four in the space of one millimetre. At intervals of 2.5 to $3 \mathrm{~mm}$ are clusters of larger cells, and at about the same interval occur slightly defined monticules. The clusters and the monticules are not necessarily coincident nor are they necessarily the centres of the quincuncial systems.

Tangential sections show that the ordinary zooecial tubes are nearly or quite circular but that they become elliptical as the centres of the clusters are approached. The walls of the zooecial tubes are comparatively thin and independent, touching each other in the direction of the rows but separated in other directions by a number of large angular mesopores. Cystiphragms appear in nearly every tube. Acanthopores are scarcely to be discerned but there is some evidence of very small ones at the points of junction of the tubes.

Vertical sections, where ideally cut, show about five well-developed cystiphragms and clearly defined diaphragms in the zooecia, the latter being confined to the lower part of the tube. The mesopores are crowded with diaphragms.

This species has decidedly the surface characteristics and manner of growth of the genus Aspidopora and approaches very closely to Aspidopora newberri [sic] Nicholson. We would without hesitation, ascribe the species to Aspidopora were it not for the undoubted diaphragms in the zooecial tubes.

Except for the somewhat larger size, the species closely resembles Prasopora lenticularis Ulrich. The vertical sections are almost identical, but the tangential section of $P$. lenticularis shows a closer spacing of the zooecial tubes and a less development of mesopores. The arrangement of the zooecial tubes in rows is apparently a feature of both species.

\section{Emended Description}

Six very poorly preserved specimens are listed as syntypes of Prasopora donensis. Only two warrant redescription and become the lectotype and paralectotype. Three are designated Prasopora cf. donensis, and one represents the brachiopod Trematis millepunctata Hall.

\section{EXTERNAL FEATURES}

Zoarium a small, free discoidal mass adhering to matrix, larger specimen before sectioning, $17 \mathrm{~mm}$ in diameter, a little over $1 \mathrm{~mm}$ in height; slightly convex above concave below, concentrically wrinkled epitheca recognized only by impression on matrix of a small portion of the base; monticules almost flush with surface, 2.5 to $3 \mathrm{~mm}$ apal . measuring from centre to centre, zooecia in inter-areas quincuncially arranged. 


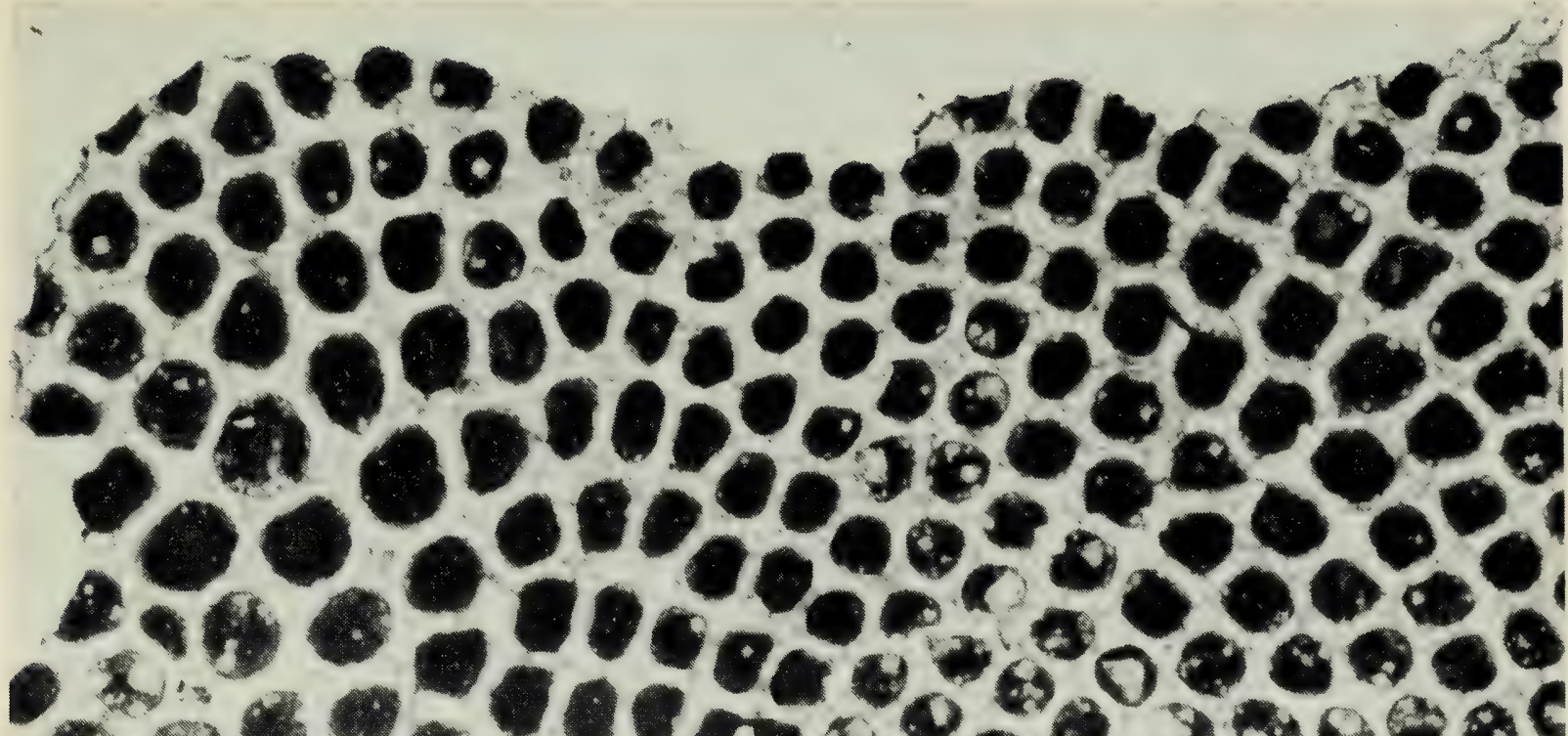

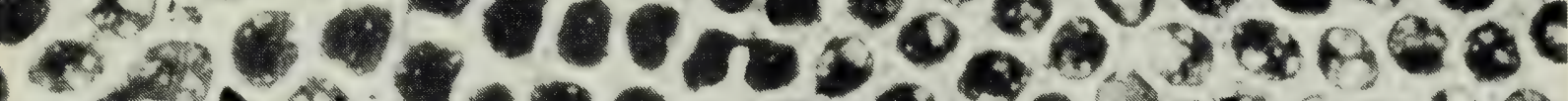

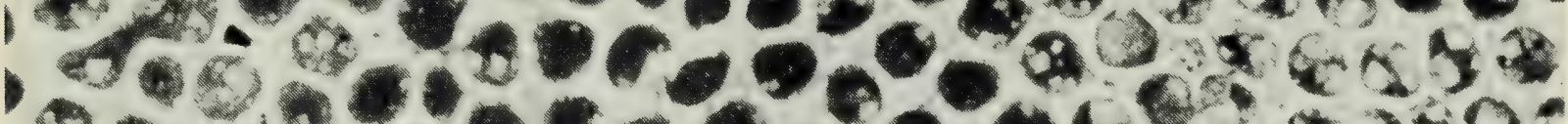

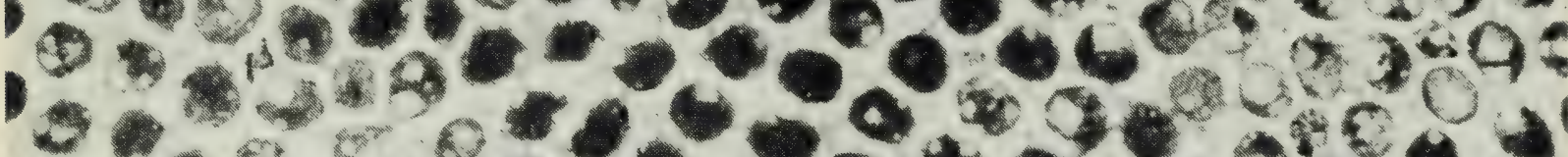

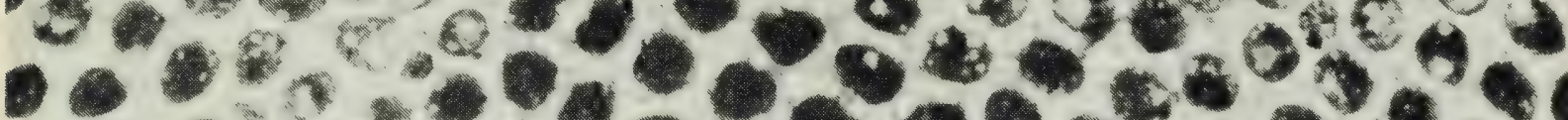

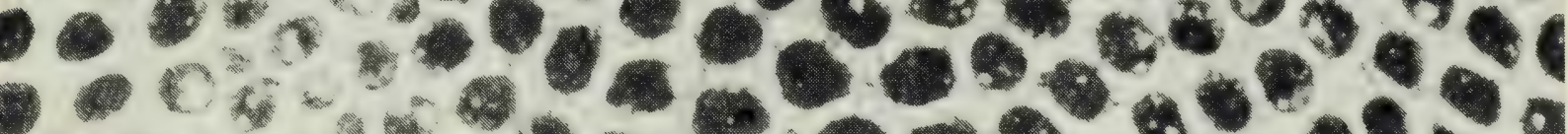

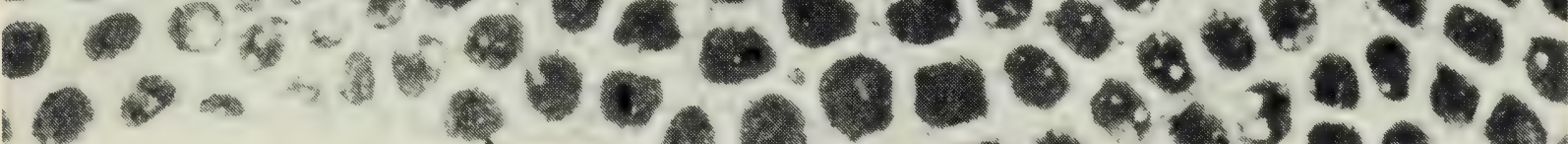
A

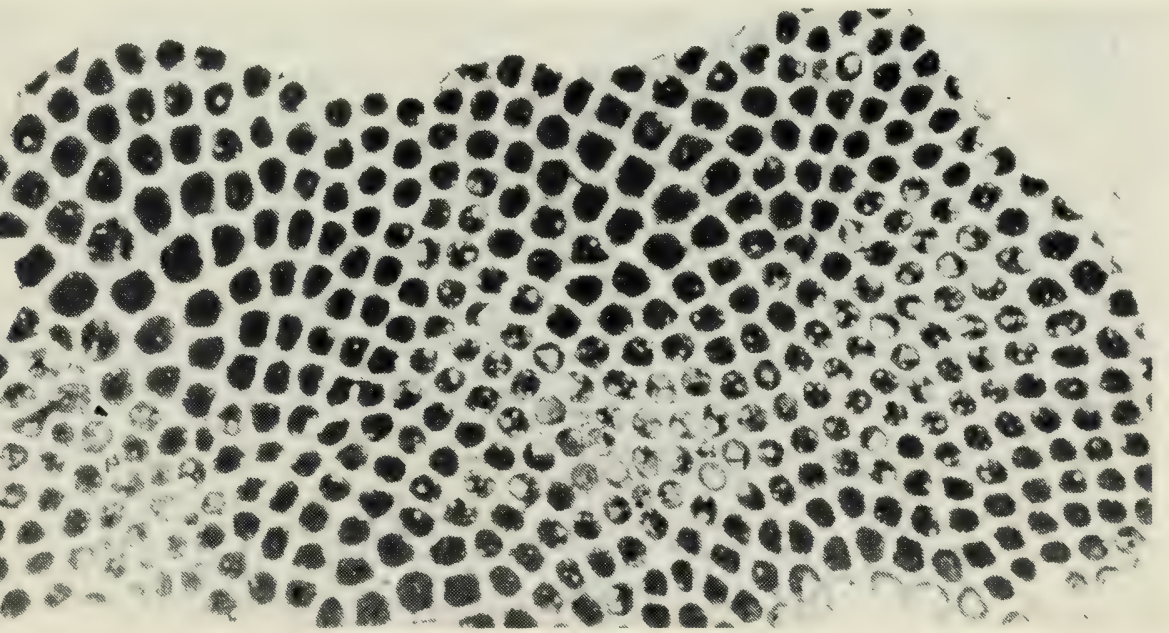

B

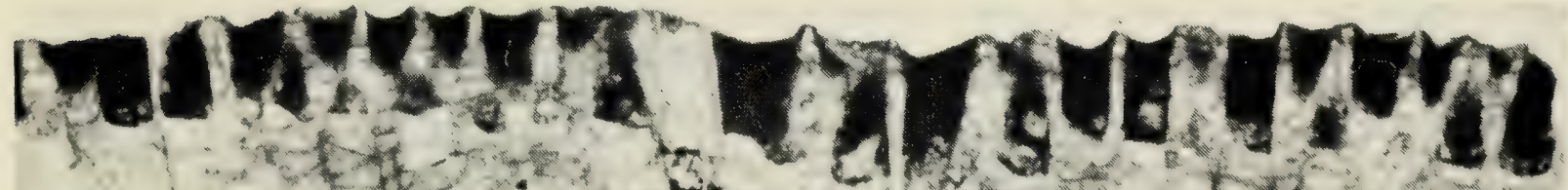

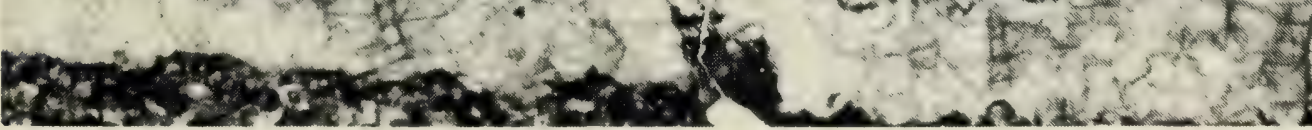

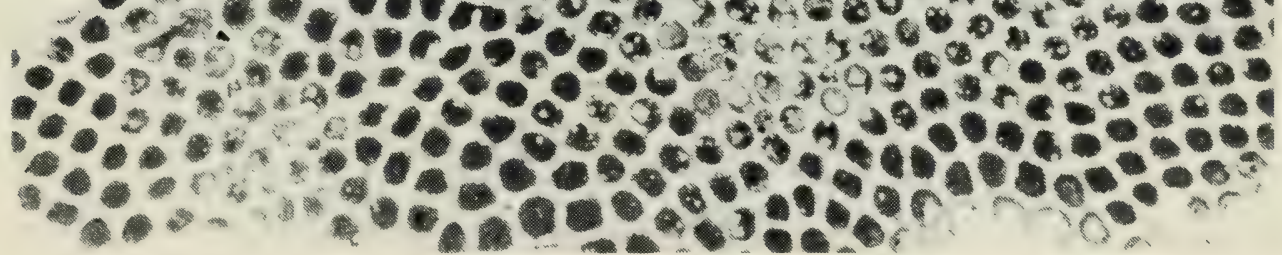

C

Fig. 4 A-C Prasopora donensis Parks and Dyer, lectotype, ROM 1084HR.
A. Tangential section, $\times 24.3$
B. Tangential section, $\times 12.2$
C. Longitudinal section, $\times 24.3$ 
TANGENTIAL SECTION

Zooecial apertures oval to circular, commonly 8 to 9 in $2 \mathrm{~mm}$ (Table 4). Zooecial wall thin $0.01 \mathrm{~mm}$ (or less) in width, finely laminated, individual laminae distinguishable only under magnifications of $\times 250$ or higher. Ordinary zooecia surrounded by numerous angular mesopores, mesopores in $1 \mathrm{~mm}^{2} 19$ to 37 (Table 4), some one-third to one-half size of a zooecium, only rarely do zooecia come in contact, acanthopores absent, cystiphragms in most zooecia. Monticules composed of zooecia larger than those in intermonticular areas and with interspersed mesopores, maximum diameter zooecial aperture in monticular areas in mm 0.26-0.31 (Table 4); maximum diameter zooecial aperture in intermonticular areas in $\mathrm{mm} 0.13-0.19$ (Table 4$)$.

\section{LONGITUDINAL SECTION}

Zooecia, slightly recumbent in peripheral zone, erect in central area, intersect zooecial surface approximately at right angles. Zooecial walls finely laminate, distinct under high magnification, in best preserved sections five cystiphragms on one side only, large at base, diminishing in size towards surface, basal cystiphragms may extend half way (or even farther) across a zooecium; straight or oblique diaphragms, corresponding in number to cystiphragms, extend from cystiphragms to opposite zooecial wall.

\section{Remarks}

$P$. donensis is significantly different from $P$. richmondensis sp.nov. (description to follow) externally in that it lacks the conspicuous nodular surface of that species; internally in the absence of acanthopores, the presence of more numerous mesopores, and smaller zooecia in the intermonticular areas.

Closely related to $P$. donensis is $P$. lenticularis Ulrich (1893: 253), from the Black River (Decorah) of St. Paul, Minnesota. The zoarium of the latter taxon is parasitic, a feature which may not be significant. $P$. lenticularis has somewhat smaller zooecia and only a single mesopore between the zooecia in the intermonticular areas, a sharp contrast to the numerous mesopores in the same areas in $P$. donensis. Owing to the extremely poor preservation of types some doubt exists as to the generic reference.

\section{Locality}

Dundas Formation, Don Valley Quarry, Toronto, Ontario.

\section{Types}

Lectotype ROM 1084HR, paralectotypes ROM 32317 and 32318. 


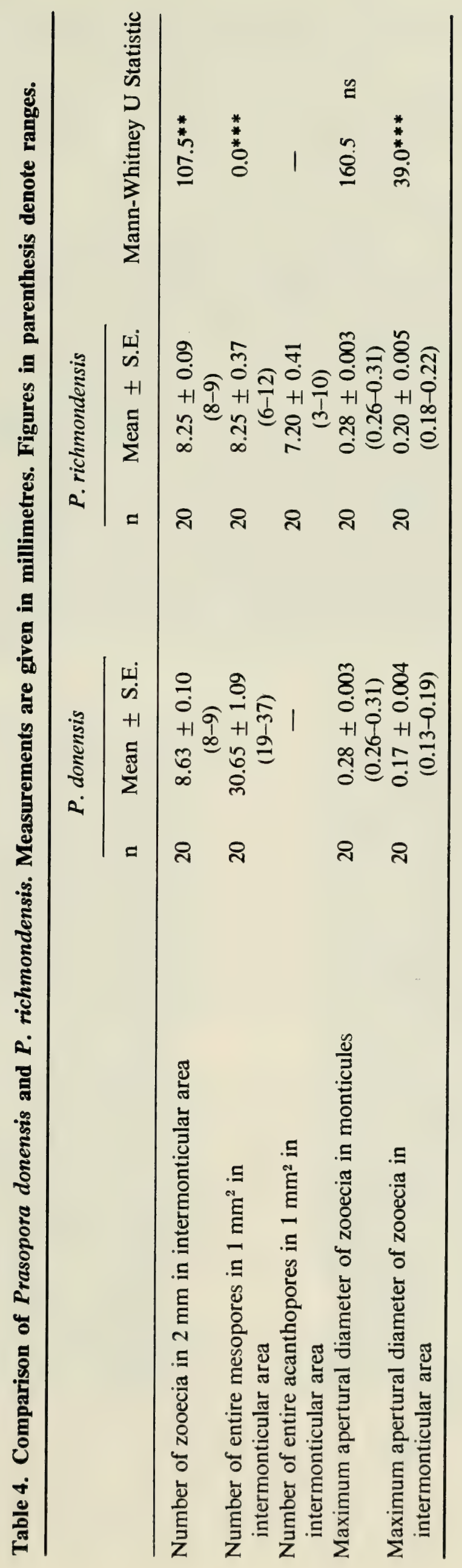




\section{Prasopora richmondensis sp.nov.}

Fig. 5A-C

Monticulipora parasitica multipora Dyer, 1925: 71.

\section{Description}

Dyer (1925) included the specimen RoM 12169, herein described, among the syntypes of Monticulipora parasitica multipora. He must have based his identification upon the somewhat similar nodular surface of the zoarium of his variety. Thin sections prepared from the specimen for this revision indicate that it represents the new species $P$. richmondensis.

EXTERNAL FEATURES

Zoarium an irregular shaped mass, part of which encrusts the brachiopod Hebertella or Platystrophia. Specimen $15 \mathrm{~mm} \times 17 \mathrm{~mm}$, greatest thickness $1.75 \mathrm{~mm}$, petering to $1 \mathrm{~mm}$ at periphery. Surface with prominent irregularly spaced unequal monticules, the smaller of which are conical, others larger and stouter, still others coalesce to form elongate elevations.

TANGENTIAL SECTION

Zooecia mostly circular but slightly angular near surface, commonly 8 to 9 in $2 \mathrm{~mm}$ (Table 5), zooecial walls thin, concentric laminae only faintly distinguishable, walls generally less than $0.01 \mathrm{~mm}$ thick below surface, 0.01 to $0.02 \mathrm{~mm}$ near surface. Mesopores, small and angular, rarely one-third size of zooecia, surround most zooecia (Table 5) and less abundant where zooecia are subangular. Acanthopores moderately abundant (Table 5), 0.02 to $0.05 \mathrm{~mm}$ in diameter with small lumen surrounded by dark concentric laminae, occasionally acanthopores indent zooecial aperture. Monticules composed of larger zooecia than in intermonticular space and with interspersed mesopores. Cystiphragms occupy from one-half to one-third area within each zooecium. Maximum apertural diameter of zooecia in monticules in $\mathrm{mm} 0.26-0.31$ (Table 5); maximum apertural diameter of zooecia in intermonticular areas $0.18-0.22 \mathrm{~mm}$ (Table 5).

LONGITUDINAL SECTION

Zooecia arise directly from the brachiopod and free basal portion and continue in a straight course to the surface of the zoarium. Walls uniformly thin throughout. Each zooecium with cystiphragms and straight diaphragms in regular sequence throughout their length, within space of $1.75 \mathrm{~mm} 12$ cystiphragms and 12 diaphragms occur. Acanthopores with clear central area, flanked by fine laminae, appear at various levels through the entire growth.

\section{Remarks}

$P$. richmondensis sp.nov. may be distinguished from $P$. donensis Parks and Dyer by the conspicuous nodular surface, by the presence of acanthopores, and by fewer mesopores. The taxon is similar to P. nodosa Ulrich $(1882 \mathrm{~b}: 245)$ in external appearance, although Ulrich did not consider the zoarium to be parasitic. Through the courtesy of R. S. Boardman and D. A. Dean of the United States National Museum, I have been privileged to examine Ulrich's syntypes of $P$. nodosa (USNM 43691) from the Trenton (Cathys Limestone), Nashville, Ten- 


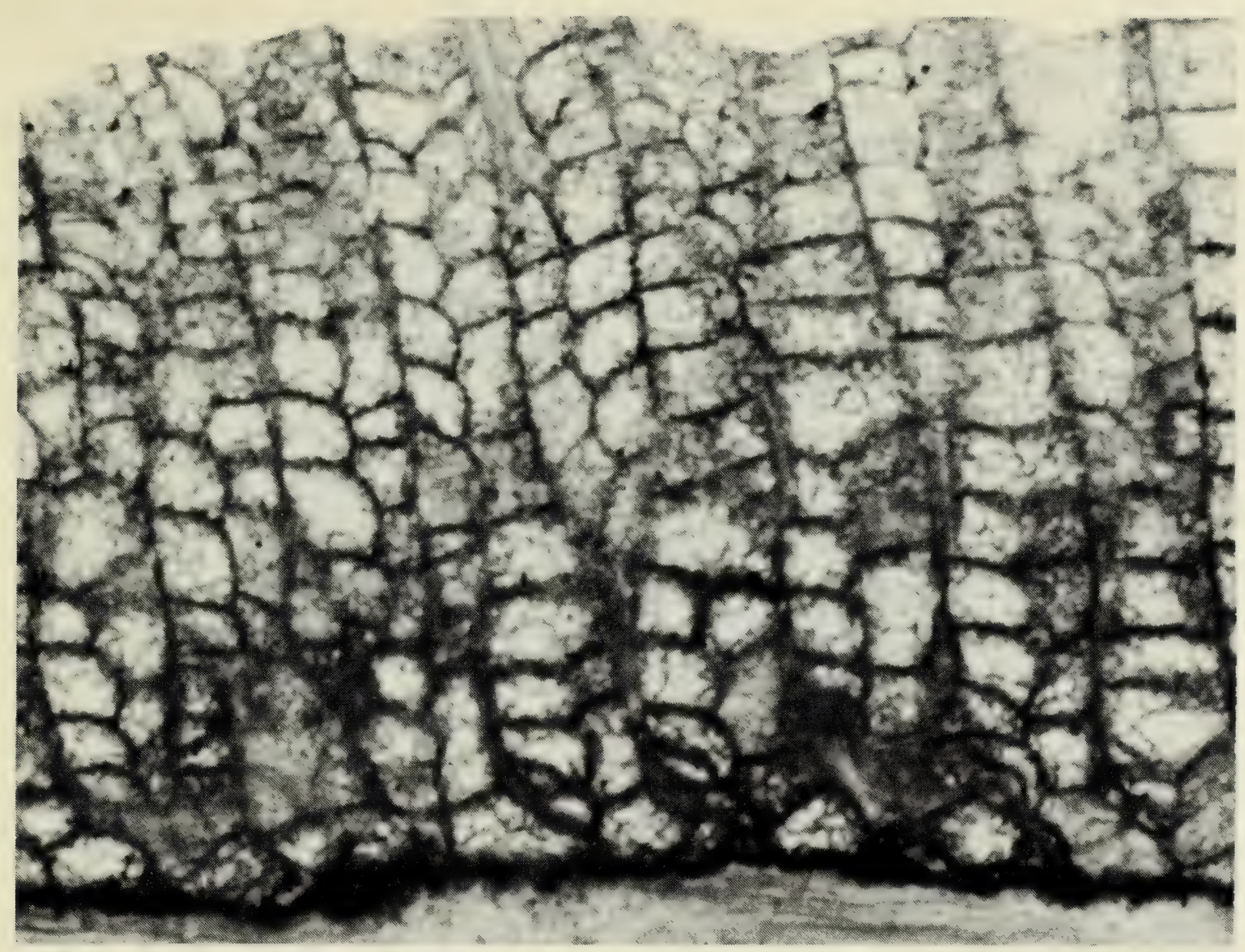

A
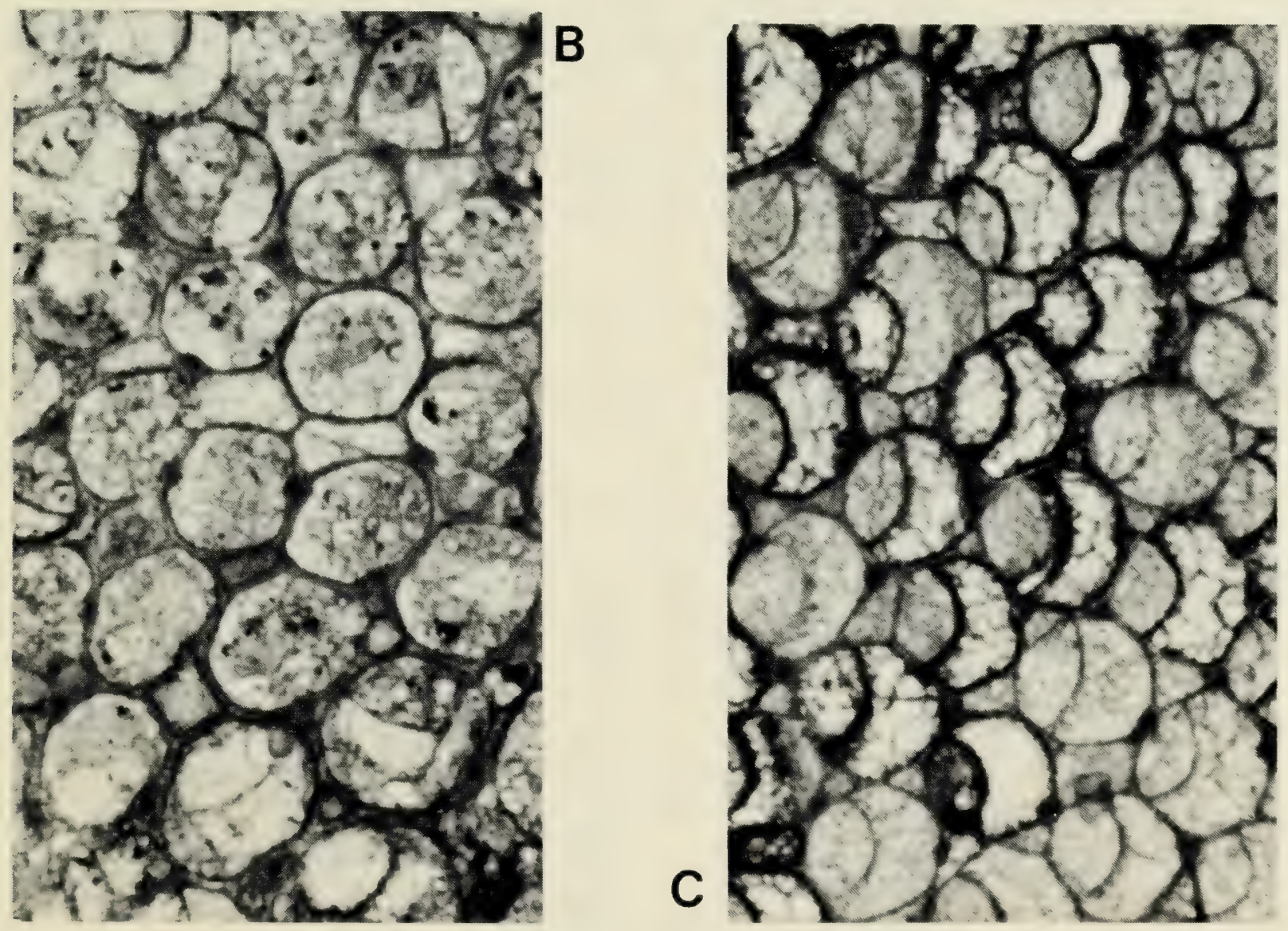

Fig. 5 A-C. Prasopora richmondensis sp.nov., holotype, Rом 12169.
A. Longitudinal section, $\times 48.6$
B. Tangential section, $\times 48.6$
C. Tangential section, $\times 48.6$ 


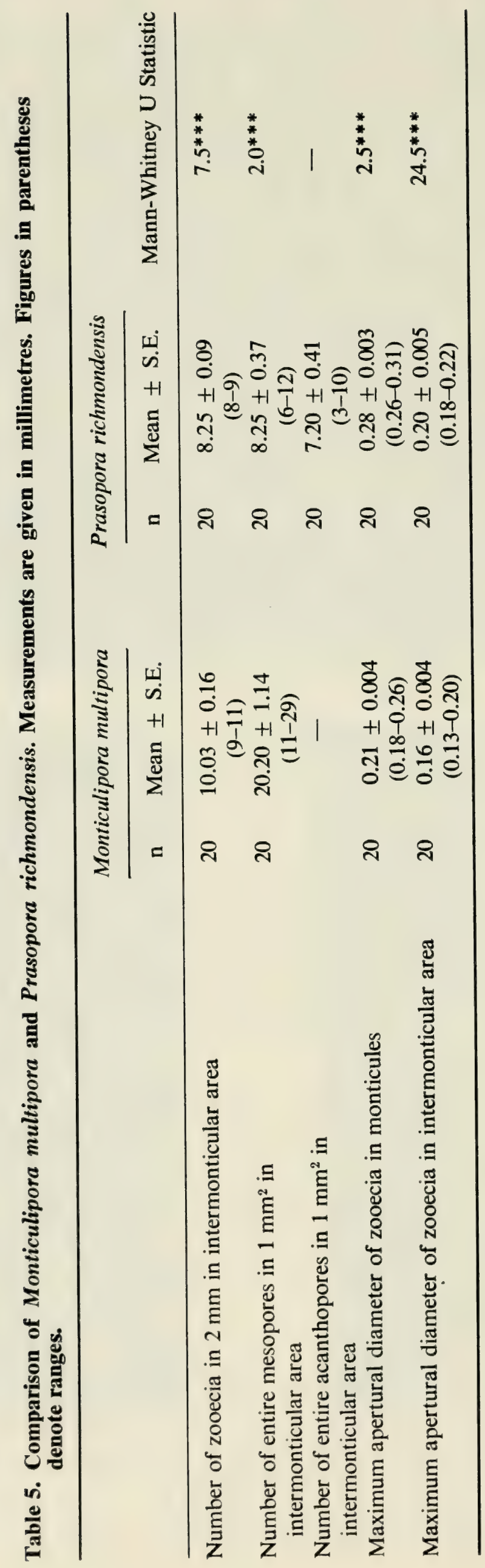


nessee. The two are similar externally and in the number of zooecia in $2 \mathrm{~mm}$ in the intermonticular areas. The monticules, however, are dissimilar; in $P$. nodosa numerous tiny, angular mesopores, varying in shape and size, surround the zooecia or form elongate, stellate, or irregular aggregations. Ulrich states that "a moderate number of spiniform tubuli may be observed in tangential sections". I fail to distinguish these structures in his sections. It is possible he confused them with the solid ends of pinched-out mesopores. No acanthopores are visible in his longitudinal sections.

To describe a new species on a single specimen is admittedly a weakness, nor have I been able to locate a comparable species from a similar stratigraphic horizon after a careful perusal of the pertinent literature available to me. As pointed out in the preceding paragraph, Prasopora nodosa Ulrich from the Middle Ordovician (Trenton) is the closest species with which Prasopora richmondensis may be compared. It is conceivable that Prasopora richmondensis is an evolutionary derivative of that older taxon.

\section{Locality}

Meaford Formation, Streetsville, Ontario.

\section{Type}

Holotype ROM 12169. 


\section{Acknowledgments}

Thanks are expressed to Janet Waddington, Curatorial Assistant, Department of Invertebrate Palaeontology, ROM, for calculating the Mann-Whitney U Statistics; to Huibert Sabelis for the restoration of original thin sections and for the preparation of new sections required for the research; to Joan Burke for her valued secretarial assistance and for typing the manuscript.

The photographs were taken by Mr. Brian O’Donovan, Department of Geology, University of Toronto. 


\section{Literature Cited}

AMI, $\mathrm{H}$.

1892 Notes and descriptions of some new or hitherto unrecorded species of fossils from the Cambro-Silurian (Ordovician) rocks of the Province of Quebec. -Canadian Record of Science, 5(1): 96-103.

ARMSTRONG, H. S.

1945 Stigmatella in the Ordovician of the Central Ontario Basin. -Journal of Paleontology, 19(2): 149-157.

BOARDMAN, R. S. and J. UTGAARD

1966 A revision of the Ordovician bryozoan genera Monticulipora, Peronopora, Heterotrypa, and Dekayia. -Journal of Paleontology, 40(5): 1082-1108.

CUMINGS, E. R. and J. J. GALLOWAY

1913 The stratigraphy and paleontology of the Tanner's Creek section of the Cincinnati series of Indiana. -37th Report, Indiana Department of Geology, Natural Resources, 1912: 353-479.

D'ORBIGNY, A. D.

1849 Prodrome de paléontologie stratigraphique universelle des animaux mollusques \& rayonnés, faisant suite au cours élémentaire de paléontologie et de géologie stratigraphiques. Vol. 1. -Paris, V. Masson. 394 pp.

DYER, W. $S$.

1925 The stratigraphy and paleontology of Toronto and vicinity. Part V. The paleontology of the Credit River section. -Report of the Ontario Department of Mines, 1923. 32(7): 47-88.

FOERSTE, A. F.

1924 Upper Ordovician faunas of Ontario and Quebec. -Memoir of the Geological Survey Branch, Canada, 138: 1-255.

FRITZ, M. A.

1970 Redescription of type specimens of the bryozoan Hallopora from the Upper Ordovician of Toronto region, Ontario. -Proceedings of the Geological Association of Canada, 21: 15-23.

1971 The trepostomatous bryozoan Stigmatella catenulata diversa Parks and Dyer (1922), a synonym for Mesotrypa diversa (Parks and Dyer). -Life Science Occasional Paper, Royal Ontario Museum, 18: 1-6.

1973 Redescription of type specimens of bryozoan Stigmatella from the Upper Ordovician of the Toronto region, Ontario. -Life Science Contribution, Royal Ontario Museum, 87: 1-31.

1975 Redescription of type specimens of the bryozoan Heterotrypa from Upper Ordovician rocks of the Credit River valley, Ontario, Canada. -Life Science Contribution, Royal Ontario Museum, 101: 1-30.

LIBERTY, B. A.

1969 Palaeozoic geology of the Lake Simcoe area, Ontario. -Memoir of the Geological Survey Branch, Canada, 355: 1-201.

NICHOLSON, H. A.

1874 Description of species of Chaetetes from the Lower Silurian rocks of North America. -Quarterly Journal of the Geological Society of London, 30(38): 499-515.

1879 On the structure and affinities of the "tabulate corals" of the Palaeozoic period, with critical descriptions of illustrative species. -Edinburgh, W. Blackwood. 342 pp.

1881 On the structure and affinities of the genus Monticulipora and its sub-genera, with critical descriptions of illustrative species. -Edinburgh, W. Blackwood. 240 pp. 
NICHOLSON, H. A. and R. ETHERIDGE, JR.

1877 L. Contributions to Micro-Palaeontology. -II. On Prasopora grayae, a new genus and species of Silurian corals. -The Annals and Magazine of Natural History, 4th series, 20(119): 388-392.

1878 Description of species. Monograph of Silurian fossils of the Girval district, Ayrshire, Scotland. Fasc. 1. -Edinburgh, W. Blackwood. 135 pp.

NICKLES, J. M.

1905 The Upper Ordovician rocks of Kentucky and their bryozoa. -Bulletin of the Geological Survey of Kentucky, 5: 1-64.

PARKS, W. A.

1924 Upper Ordovician at Toronto, Ontario. -Bulletin of the Geological Society of America, 35(1): 103-104 [Abstract].

1925 Addenda et Corrigenda (Parts I to IV). -Report of the Ontario Department of Mines, 1923, 32(7): 35-38.

PARKS, W. A. and W. S. DYER

1922 The stratigraphy and paleontology of Toronto and vicinity. Part II. -The Molluscoidea. -Report of the Ontario Department of Mines, 1921, 30(7): 1-59.

ROMINGER, C.

1866 Observations on Chaetetes and some related genera, in regard to their systematic position; with an appended description of some new species. -Proceedings of the Academy of Natural Sciences of Philadelphia, 18: 113-123.

ROSS, J. P.

1970 Champlanian Ectoprata (New York State), Pt. III. -Journal of Paleontology, 44(2): 346-382.

SIEGEL, S.

1956 Nonparametric statistics for the behavioral sciences. -New York, McGraw-Hill. $312 \mathrm{pp}$.

ULRICH, E. O.

1882a American Palaeozoic Bryozoa. -Journal of the Cincinnati Society of Natural History, 5(3): 121-175.

1882b American Palaeozoic Bryozoa. - Journal of the Cincinnati Society of Natural History, 5(4): 232-257.

1886 Lower Silurian Bryozoa of Minnesota with preliminary descriptions of some new species. Minnesota Geological and Natural History Survey, 14th Annual Report (III). -J. W. Cunningham \& Co., State Printers, St. Paul, Minnesota: 57-103.

1888 A correlation of the Lower Silurian horizons of Tennessee and of the Ohio and Mississippi Valleys with those of New York and Canada. -The American Geologist, 2(4): 39-44.

1890 Part II. Palaeontology of Illinois. Section VI. Palaeozoic Bryozoa. - In Worthen, A. H. Geological Survey of Illinois. Volume 8. Geology and Palaeontology. Edited by J. Lindahl, Springfield, Ill. Published by authority of the Legislature of Illinois, pp. 285-677.

1893 On the Lower Silurian Bryozoa of Minnesota. The Geological and Natural History Survey of Minnesota, 1895. -Harrison \& Smith, State Printers, 3(1): 96-332.

ULRICH, E. O. and R. S. BASSLER

1904 A revision of the Paleozoic Bryozoa. Part II. On the genera and species of Trepostomata. -Smithsonian Miscellaneous Collections, 47: 15-55.

UTGAARD, J. and T. G. PERRY

1964 Trepostomatous bryozoan fauna of the upper part of the Whitewater Formation (Cincinnatian) of eastern Indiana and western Ohio. -Bulletin of the Indiana Department of Conservation, Geological Survey, 33: 1-111. 



